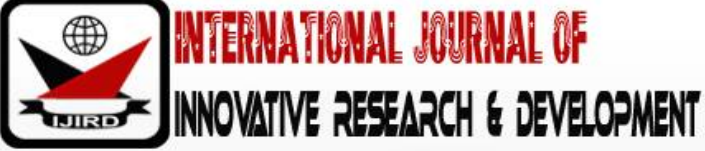

ISSN 2278 - 0211 (Online)

\section{Folklore in the Cultural Awakening of Amadi- Ama People in Port Harcourt City Local Government Area of Rivers State, Nigeria}

\author{
Dr. Barigbon Gbara Nsereka \\ Senior Lecturer, Department of Mass Communication, \\ Rivers State University, Port Harcourt, Nigeria \\ Angel Tamunoibime Koko \\ Research Assistant, Department of Mass Communication, \\ Rivers State University, Port Harcourt, Nigeria
}

\begin{abstract}
:
Considering that the importance of folklore in development, especially cultural development, in communities seems to be lost to the present generation of young people, this study was carried out to determine the possible role of folklore in reawakening the cultural consciousness of the people of Amadi-Ama in Port Harcourt City Local Government Area of Rivers State, Nigeria, with a view to harmonizing and galvanizing the people who, unlike their forbears, seem not to know the importance of folklore which welded together the people of old through mutual trust and love for one another. To accomplish the objective, the qualitative research techniques of focus group discussion and semi-structured interview were adopted to gather data which were analyzed using critical discourse analysis. Findings showed, among other things, thatto promote cultural awakening in Amadi-Amadi, there is the need to introduce folklore and proverbs in the homes and introduce the teaching of folklore, especially those that can inculcate moral virtues in children and youths. Concluding that African societies are fast losing their essence and identity due to self-denial, the study recommended that it is important to convert folklore into readable forms in books and on the Internet, so as to not only preserve it but for it to also attract younger readers.
\end{abstract}

Keywords: Folklore, proverbs, cultural awakening, Amadi-Amadi, Nigeria

\section{Introduction}

The concept of culture consists of the values the members of a given group hold, the norms they follow, and the material goods they create. This refers to the way of life of the individual members or groups within a society, how they dress, their religious ceremonies, and leisure pursuits (Adesoji, 2005). It also includes their rules of behaviour, language, rituals, arts and economic systems. So, culture is the totality of the way of life of a people through which they associate and relate with their environment. Kanagy and Kraybill (1999) cited in Adesoji (2005) describe culture as a set of tangible and intangible things like diet, tools, technology and values that give shape and meaning to the everyday life of a particular group of people. Culture is usually established from enlightenment, acquired through education, observation and exposure to an environment.

A nation or continent whose cultural values (the basis of its tourist attraction for economic viability) gradually sink into the sand of extinction, will soon cease to enjoy universal respect, admiration, uniqueness and identity (http:/ / ifawoodlandpark.com/ the-need-for-reawakening). Apparently, this is the plight of the African nations. African children no longer appreciate whatever defines African states as independent states that were fought for (spilling tears and blood) in order that the names should be engraved or stenciled on the mental sheet of succeeding generations. Instead, and regrettably too, they feel more comfortable and find it more convenient to identify with the West in all ramifications including colour, tongue and other racial factors. For instance, African youths' irresistible passion for foreign games such as European football, etc, is quite alarming, a behaviour that seriously threatens Africa's cultural or traditional games. It is disheartening that right before their parents and mentors, African children and youths drift away from the path of their birth to that of slavery and enslavement.

At the 8th Annual Forum of Laureates of the Nigerian National Order of Merit (NNOM), the Director-General, National Orientation Agency, Mr Mike Omeri, in a paper entitled "Traditional African Culture and Issues of Corruption", said the ongoing anti-corruption campaign of President Muhammadu Buhari was a call to cultural re-awakening. According to Mr. Omeri, to successfully address the problem of corruption in Nigeria, a programme of cultural reawakening was imperative. Cultural awakening refers to the shaping or modelling of peoples' consciousness and 
awareness to the complexities of issues that form their way(s) of life. African communities, including Amadi-Ama and other communities in Port Harcourt city Local Government Area of Rivers State, have very rich cultures that require reawakening. Africa is not only unique in customs, traditions, and culture, but also in its means of communication. All the means of communication originated from the earliest Africans in the old Egypt, the cradle of civilization, which later spread to China, India, Greece and Rome (NOUN, 2009).

The culture of a people is usually reflected in its folklore. Folklore is the traditional art, literature, knowledge, and practice that is disseminated largely through oral communication and behavioural example. Every group with a sense of its own identity shares, as a central part of that identity, folk traditions-the things that people traditionally believe (planting practices, family traditions, and other elements of worldview), do (dance, make music, sew clothing), know (how to build an irrigation dam, how to nurse an ailment, how to prepare barbecue), make (architecture, art, craft), and say (personal experience stories, riddles, song lyrics) (http: / / www.afsnet.org/ ?page=WhatIsFolklore, p.1).

Folklore deals with the beliefs, traditions, experiences and superstitions of a people transmitted from generation to generation through oral tradition (Nwanne, 2006). Essentially, folklore worries about how the cultural norms of a people are transmitted from parents to their children. This is important in the traditional African communication, which has remained largely oral. Folklore comprises prose narratives such as legends, folktales, myths and fables. Folklore is an integral part of any culture. In the olden days, elders gathered young ones, especially children, totell them stories of dead people that had shown bravery, of animal kingdom, birds, reptiles, and the gins. Those stories (folktales) have the capacity to sensitize children to the immediate environment; help children develop self-confidence; sharpen the children's survival instinct; increase the children's patriotic activities; and enhance their moral development.

\subsection{The Problem}

Unlike the modern media, folklore as a medium of communicating tribal or social reality and morality, is democratic, interactive and unrestrictive, in terms of usage. Using such a free and unrestricted medium to reawaken the cultural consciousness of the Amadi-Ama people of Port Harcourt City Local Government Area (PHALGA) will facilitate a revival of socially sanctioned values upon which the cultural well-being of society is anchored.

Yet the importance of folklore in development, especially cultural development, of society, seems to be lost to the present generation of young people. Such cultural practices as respect for elders; moralizing displays like masquerading; folk dances, story-telling; discipline; peace and high regard for the sanctity of human life; and voluntary protection of public or personal property; seem to be disappearing from society. Disturbed by the trend, this work sought to investigate the use of folklore in the cultural awakening of Amadi-Ama in PHALGA.

\subsection{Objectives of the Study}

Broadly, the objective of this study was to determine the possible role of folklore in re-awakening the cultural consciousness of the people of PHALGA with a view to harmonizing and galvanizing the people who, unlike their forbears, seem not to know the importance of folklore which welded together the people of old through mutual trust and love for one another, and their high moral standing.

Specifically, the study sought to:

- Identify some common folkloric activities that are geared towards development.

- Determine the areas of importance of folklore among the indigenous people of Amadi-Ama.

- Ascertain the relative importance of folklore in cultural development.

- Explore ways by which folklore can be used to engender cultural awakening.

From the above objectives, the study sought answers to the following questions:

- What are common folkloric activities that are geared towards development?

- What are the areas of importance of folklore among the indigenous people of Amadi-Ama?

- What is the importance off olklore in cultural development?

- In what ways can folklore be used to engender cultural awakening?

\subsection{Theoretical Framework and Literature}

This study is hinged on the Development Communication and Socio-cultural theories. The development communication theory's emphasis, as explained by Udoakah (1998), is on how to use the media to redress the battered image of developing countries, especially such bad image given by the Western media; a resolve to use the mass media to bring citizens together, using reporting techniques and programmes considered most appropriate and the determination to use the mass media for social engineering that would bring about wealth and thereby ensure individual and collective well being. This no doubt, is meant to bring about change. Change and adoption of new ideas are said to be synonymous with development. Development on the other hand, in the words of Mabogunje as quoted by Adesanoye (1990), "is a process of moving the whole social system upward to realize its inherent potential and to effectively cope with the changing circumstances of its life.... It is essentially concerned with mobilizing communities and society as a whole to engage in the task of self-improvement with the resources available" (p.36). It is in line with this theory that this work sought to investigate the place of folklore in the cultural awakening of the people of Amadi-Ama in PHALGA.

\subsection{Folklore: What is it?}

The term folklore is generally used to refer to the traditional beliefs, myths, tales, and practices of a people which have been disseminated in an informal manner. 
The term "folklore" was first coined by William J. Thoms in 1846. Thoms was a British antiquarian who wanted a simple term to replace various awkward phrases floating around at thetime to discuss the same concept, phrases such as "popular antiquities", "the lore of the people", and "the manners, customs, observances, superstitions, ballads, proverbs etc, of the olden times".

Oring (2011) writes that folklore can be described as traditional art, literature, knowledge, and practices that are passed on largely through oral communication. According to him, the information thus transmitted expresses the shared ideas and values of a particular group. And that folklore is that part of culture that "lives happily ever after."

In the academic world, the study of folklore is most often known as folkloristics, although it is sometimes also termed folklore studies or folklife research. As an academic discipline, folklore shares methods, and insights with literature, anthropology, art, music, history, linguistics, philosophy, and mythology.

From the above, it can be deduced that the most common definitive element in folklore is its representation of oral tradition, that is, traditions that have been transmitted in an oral manner. This definition has several issues. In non-literate societies, for example, all culture is orally transmitted, making the concept of folklore in such a context all-encompassing. Moreover, even in literate societies, there are many activities, such as brushing one's teeth or driving a vehicle, which are orally transmitted and yet not usually thought of as folklore.

Accordingly, oral transmission alone is not seen as something that is enough to make something folkloric. Also problematizing the link between folklore and oral tradition is the fact that some practices that are widely deemed folkloric, such as epitaphs or chain letters and folktales also involve transmission through text. Similarly, some other folkloric practices, such as traditional dances, games, gestures, and symbols, are often transmitted visually rather than orally.

Perhaps it will be better put in the sense Ricky (2005) says it: "Folklore can be expressed in various forms, in African society; its beauty is best perused in oral form; it represents one of Africa's longest traditions, and comes in the name of night entertainment, educative narrative, allegory etc." (p.22).

Various views have been expressed about folklore in human society with some describing it as the most important means of expressing African culture. Babara et. al (1961) assert that folklore has as an integral of oral tradition has remained strong despite the growth of formal education and marked increase in literacy rate.

Sutherland (1976) is in alliance with this line of thought, he says:

Folklore is the most functional aspect of the traditional verbal art, and through it the beliefs morals and social attitudes of the people are transmitted from one generation to another. So powerful is this medium that it survived the destructive influence of the missionary activities and colonialism ( $p .8$ She, however, regrets that in contemporary African society, there is dearth of official patronage of this cultural means of expression, especially as an academic are of study and investigation. According to her, it is unfortunate and very necessary to encourage African arts experts to acquire more knowledge of their own indigenous games in the first place. Continuing, Sutherland (1976) says:

In view of this, one cannot say with any measure of equanimity that the highly educated segment of our people knows and gives it worthy notice.

The necessity arises because of the dreadful history of how these games have been discouraged, or virtually banned by educational policy; neglected or with disdain in educational institutions (p.212).

According to Chaudhury (2013) the term folklore has acquired a variety of meanings down the ages, however, in common parlance, the term folklore could be understood to denote the traditional expressions of a people as seen in their proverbs, songs, tales, legends, myths and riddles He describes folklore as an inviolable part of the life of an African community, being a favorite recreation to many and a means of educating the mind within the fold of the community. In Chaudhury's view, folklore in traditional societies has highly educative value, it imparts knowledge on the groups' history, values of warfare, morals, wise sayings etc.

Folklore is usually expressed through word of mouth, although in modern times the Internet has become a pivotal source of folklore. The term folklore may also be used to define the comparative study of folk knowledge and culture. Folklore is oral history that is preserved by the people of a particular culture, consisting of traditions belonging to that culture. These traditions usually include music, stories, history, legends, and myths. Folklore is passed down from generation to generation and is kept active by the people in the culture.

Sims and Stephens (2005) believe that folklore is many things, and it is almost impossible to define it succinctly. It is both what folklorists study and the name of the discipline they work within. It is folk songs and legends. Folklore exists in cities, suburbs and rural villages, in families, work groups and dormitories. Folklore is present in many kinds of informal communication, whether verbal (oral and written texts), customary (behaviours, rituals) or material (physical objects). "It involves values, traditions, ways of thinking and behaving. It is about art. It is about people and the way people learn. It helps us learn who we are and how to make meaning in the world around us" (p. 1-2)Noyes (2014), in his way, defines folklore as a meta-cultural category used to mark certain genres and practices within modern societies as being not modern. By extension, the word refers to the study of such materials.

More specific definitions place folklore on the far side of the various epistemological, aesthetic and technological binary oppositions that distinguish the modern from its presumptive contraries. Folklore therefore typically evokes both repudiation and nostalgia (p.375).

Klein (2001) sees folklore as having four basic meanings. First, it denotesoral narration, rituals, crafts, and other forms of vernacular expressive culture. Second, folklore, or folkloristics names an academic discipline devoted to the study of such phenomena. Third, in everyday usage, folklore sometimes describes colourful 'folkloric' phenomena linked to the music, tourist, and fashion industries. Fourth, like myth, folklore can mean falsehood. 
Hufford (1991) calls folklore folklife. He says folklife, like Edgar Allan Poe's purloined letter, is often hidden in full view, lodged in the various ways we have of discovering and expressing who we are and how we fit into the world. Folklife is reflected in the names we bear from birth, invoking affinities with saints, ancestors, or cultural heroes. Folklife is the secret languages of children, the codenames of CB operators, and the working slang of watermen and doctors. It is the shaping of everyday experiences in stories swapped around kitchen tables or parables told from pulpits. It is the African American rhythms embedded in gospel hymns, bluegrass music, and hip hop, and the Lakota flutist rendering anew his people's ancient courtship songs.

\subsection{A Folkloristic Approach to Understanding Teachers as Storytellers}

Hamer (1999), in a study entitled "A folkloristic approach to understanding teachers as storytellers", had the goal of illuminating the process of learning history by looking at' history-making (Thelen, 1991; Rosenzweig \& Thelen, 1998) as performed inside the school through the lens of "history-making" as practiced outside the school. The criterion for selecting a school was that it should be located in a community with a clearly identifiable and easily accessible public interest in history. The town selected had held an annual Fall Festival since 1935, and contemporary festivals regularly commemorated local, state, and national historical events. Second, the researcher wanted a school that was not recognized in any official way as a model school, and teachers who had not been publicly recognized as exceptional. In the school chosen, all three U.S. history teachers chosen were classified as solidly mainstream American. Most importantly, all three teachers were professional and generous in their willingness to let the researcher come into their classrooms with a typically vague qualitative research agenda of wanting to understand how kids learn history. The study involved 14 months of participant-observation, supplemented by semi-structured interviews.

One of the findings was that the process of telling stories about distant times and places from one source and retelling them with reference to other times when the stories have been told, as well as reference to oneself and one' $s$ immediate situation, constitutes a mediating performance. The act of decontextualizing a text from the national context and recontextualizing it into a personal or local context requires asserting the authority to make oneself a responsible agent who is central to telling about national events, and whose experiences are directly related, through the dialogic process of narrating, to national experience. Rosenzweig and Thelen (1998) authoritatively show that for adult Americans of all ethnicities, regions, and socioeconomic statuses, ' the past [is] pervasive, a natural part of everyday life.

\subsection{Developing Student Moral Value through Folklore}

In Warta's (2012) study, it was found that folklore presents not only social conflict but also suggests some ways to overcome the conflict; and that conflicts of such kind can be solved if only people are wise enough to face them. Finally, using performance level, it was also found that folklore can help develop students to be morally good students and better humans; and that students majoring in language and literature show better life to live than those with science education.

\section{Methodology}

This study used a mixed-method qualitative research method: One-session Focus Group Discussion (FGD) and semi-structured interview. The purpose of using this method was to get collective views on certain defined topics of interest from a group of people who were known to have certain experiences.

Critical case sampling was used to purposively select a few individuals whose views in the area are respected. A critical case is one that permits analytic, not inferential generalizations(Patton, 2014). Datawere analyzed by Critical Discourse Analysis (CDA).

\subsection{Critical Discourse}

2.1.1. Research Question 1: What Are Common Folkloric Activities That Are Geared Towards Cultural Development of Amadi-Ama?

This question sought to find out some folkloric activities, tales and proverbs of the Amadi-Ama people of PHALGA, Rivers State, with a view to knowing if they are geared towards development. In response, the focus group participants listed a number of folkloric activities. They explained that the people of Amadi-Ama community have a culture that is distinctive and impressive. Featuring prominently in the culture of Amadi-Ama people as folkloric activities were the Iria puberty and marriage ceremonies, wrestling, traditional plays, burial rites, installation of chiefs and traditional rulers and many other rites and plays connected with the day-to-day life of the people. One discussant added that masquerade display was equally a prominent folkloric activity of the people. The respondent described the masquerades as colourful and artistic in either their make-ups or paraphernalia. Respondents averred that in concept, these are either religious or personifications of the rich legends of the people and their classic performances backed by the refreshing poetry of songs and music, which they maintained, "bring to focus the high sense of drama and entertainment of the people". Similarly, another discussant added that a variety of dances, each unique in its form also abounded. Musical instruments include pots and drums, wooden gongs, horns and xylophones. All these were made locally by craftsmen.

Carving of Masquerades and ceremonial canoes is a revered art and carvers have greatly improved the quality of their work over the years. Discussants noted that the purely functional forms of these carvings are being given new dimension and finish that reflect the people's innate respect for aesthetic values.

Among the activities are Iria festival. In the Wakirike area, there are mainly two recognized types of marriage namely, Ya and Igwa, consummated with the knowledge and consent of the parents and relatives of both parties, religious and social taboos; burial of the dead; and transfer of power, among others. Other folkloric activities are in the form of 
sports. These include Toru Oke (swimming), Owumanji (chase and catch), Kpotein (somersaulting), EneFin (High jump) and Dein tein (Arching) (Opuogulaya, 1975). Another dominant folkloric activity in Okrika, like other Ijo sub-groups of the Niger Delta, is the organization into autonomous and co-equal war-canoe houses, as revealed by one Amadia-Amadi community member. Community members explain that although the war - canoe is an institution of kinship, historically, it deals with war and defence.

Again, as in other ethnic groups, proverbs are a cardinal part of the Amadi-Ama folklore. Focus group participants listed several proverbsamong which are the three stated below with their meanings:

- Gbori bara tungbali tibebu iku si-si-ke: A single finger cannot remove lice from the hair. Meaning:We all need one another.

- $\quad$ Aka $n$ abele na ye gina me: The teeth and the tongue do quarrel at times. Meaning: There is no perfect relationship.

- Migi olubo papa-bara: Nobody can hold water with his or bare hands. Meaning: You must use something to fetch water.

Respondents agreed on the importance of proverbs in every African society. The focus group members noted that the language of the proverbs used in Amadi-Ama is couched in intrigues and outright ambiguity, leaving the respondent with the task of "unravelling the puzzle." Mbiti (1995) describes proverbs as symbols of communication packed into short sentences, or even anecdotes and stories, sometimes carved on wood, stored on other materials or even sung or danced to. In many societies, proverbs act as a catalyst of knowledge, wisdom, philosophy, ethics and morals which provoke further reflection and call for deeper thinking and consideration of issues. Both in traditional and modern societies, proverbs are generally accepted as the quintessence of relation of ideas and ethics to the old and the young. In fact, a scenario is best explained when a speaker encapsulates his thoughts and ideas in a suitable and appropriate proverbs. It is difficult to have chieftaincy meetings and other socio-cultural activities in Amadi-Ama without ample use of proverbs by elders.

Meanwhile, Mbiti (cited in Muyingi, 2015) contends that the language of proverbs has a rich vocabulary of words, phrases, combination of words, symbols, pictures, allusions, association and comparisons. Because of the roles played by proverbs in human society, and the fact that there is hardly any conceivable situation that is not capable of attracting the usage of proverbs, creative writers use them in a deliberate search for appropriate language for their work, a style that will not only suit their subjects but will also define the moral issues which the work is concerned with.

\subsubsection{Research Question 2: In What Areas of Human Endeavour Can the Importance of Folklore among the Indigenous} People of Amadi-Ama Be Noticed?

Conversations are laced with proverbs. Amadi (2000) summarizes the role of proverbs in human society by saying that proverbs are an essential part of conversation in everyday life and that proverbs are deployed in many societies including Africa to sue for cordiality, harmony and peace. They are useful in rebuking, praising and advising. They can also be used as a comment or persuasion. Proverbs educate, warn, ridicule, console, encourage, entertain, resolve conflict and perform legal functions. Elders say certain festivals observed by the people of Wakirike in the past, some still current, reflect the culture of the people. This applies equally to certain of their customs, religious practices, and system of marriage and divorce, among others.

However, one FGD member submitted that the advent of Christianity in Amadi-Ama seemed to gradually threaten these folkloric activities. While the early Christian missionaries did a great deal of good by checking unwholesome practices and customs indulged in by people and by establishing educational institutions and health centres, they also did harm to the culture of the people. They forbade singing native songs and dancing native steps as they branded indiscriminately all such practices as heathen, instead of purifying them where necessary. Defaulters were excommunicated, thus much of the people's culture was dropped and relics embodying the story of the past destroyed.

Some respondents lamented that Christianity now brands as most ungodly, the singing of native songs accompanied with native musical instruments at the funeral of a Christian or according a dead titled man some customary ceremonies indicating his status in society such as firing of the cannon and laying the body in state on a locally made throne called tanda. It is the playing of music from imported musical instrument such as side-drums and flutes or cornets that is heavenly, according to the Christian pioneers. Meaningless foreign names were preferred to native names at baptism.

Similarly, one respondents interviewed hinted that the custom lore; marriage, chieftaincy installation, burial rites, naming among others still exists, unlike the material culture; canoe carving, net weaving, masquerade carving, artifact, among others that are on the decline. Moreso, another respondent interviewed frowned at the dearth of documented folklore that could help convey these ancient thoughts to young generation of Amadi-Ama. This concern was also raised by the Lagos Books and Arts Festival (LABAF, 2010). The forum observed that the production of literature works has continued to be as high as ever, but a disturbing number of the young writers have been shying away with the folklore and other elements of the traditional literature. LABAF observes that:

Perhaps, the new writers have found an alternative in other traditions. It may also mean a case of someone not being able to give what he or she does not have - since such writers did not live in an environment or an age where traditional literature is/ was popular (p.1

This equally captures the unfortunate trend in Amadi-Ama as not only is a there a dearth of material culturists, but also verbal lore (oral traditions) is on the brink of extinction. Verbal lore (or oral traditions; ballads, chants, country music, blessings, curses, fables, folk beliefs, fairy tales, folk songs, folktales, jokes, lullabies, oaths, prayers at bedtime, riddles, prayers at table, toasts, tongue-twisting, word games) have remained, although not with the originality and dexterity ancient practitioners had displayed. 


\subsubsection{Research Question 3: What Is The Importance of Folklore in Cultural Development?}

This question did set out to find out the importance of folklore in cultural development of Amadi-Ama community. Focus group participants interviewed provided the answer to the question.

Most respondents on the focus group maintained that folklore is a cardinal component of the African culture including that of Amadi-Ama, hence its importance to cultural development cannot be over-emphasized. However, the fact that it is declining fast is a major threat to cultural development. If those components that clearly distinguish a people from others are lacking, then it can only take a while before their identity is eroded. This is in tandem with Kanagy and Kraybill (1999) cited in Adesoji (2005) who describes culture as a set of tangible and intangible things like diet, tools, technology, language and values that give shape and meaning to the everyday life of a particular group of people. A nation or continent whose cultural values (the basis of its tourist attraction for economic viability) gradually sink into the sand of extinction, will soon cease to enjoy universal respect, admiration, uniqueness and identity (http:llijawoodlandPark.com/the-need - for reawakening). The uniqueness of the African means of communication is embedded in their originality, creativity, traditions and culture. For instance, cultural values are transmitted by these folk media of story-telling. Myths, legends, tables and folktales are information flow from one generation to the other

More so, Bausch (1999) cited in Evans (2007) notes that "every people, nation and community has stories and myths that preserve and prolong the traditions that give them their "identity" (p.13). When a nation is in trouble, it often returns to its traditional stories to look for direction and healing, to regain a sense of what made it great in the past and what will nurture it into the future. Penjore (2005) emphasizes the impact folklore can have on the formation and transmission of values. He submits that: distilled folk wisdom like proverbs... validates values and beliefs, which are reinforced practically in adult life. (Folktales) make children imagine and create their own mental pictures and this mental exercise leaves deepest impression on them, imprinting folktales' rightful place in their imagination. Folk wit and wisdom are not taught through formal arrangement, but through direct observant

\subsubsection{Research Question 4}

\subsubsection{In What Ways Can Folklore Be Used to Promote Cultural Awakening in Amadi-Ama in PHALGA?}

Focus group participants and interviewees were requested to suggest ways to promote cultural awakening in Amadi-Ama in PHALGA. To this end, most respondents emphasized the need for the introduction of folkloric education in homes. They observed that since the family is the first point of socialization and training, parents can start engaging their children in folkloric activities. It was submitted that beyond that was the need for parents to explain to them the import and implication of these activities to their wellbeing.

Meanwhile, an interviewee suggested that priority should be given to the teaching of folklore in schools, especially those aspects of folklore that can inculcate moral virtues in children. The reader combines personal knowledge and experience, knowledge of history and cultures, experience with values and ideas, and knowledge of other pieces of literature (Christenbury, 2000 cited in Yellin, 2003). Yellin contends that when teachers allow students to reflect on and share their perceptions in the classroom, the teacher is affirming the students' knowledge and participation, opening up discourse and encouraging students to "make a community of meaning" (Yellin, 2003, citing Christenbury 2000, p.99). Yellin suggests that one of the avenues to help develop this community of meaning is by examining proverbs, which are learned through oral literacy, through parental and generational teachings and through cross-cultural studies, which can be implemented in the teaching of language arts, social studies and/ or history. According to Yellin, "proverbs were and are primary tools for teaching children in all cultures and communities through the world" (p.99).

Equally suggested by discussants as a way of reawakening cultural awareness in Amadi-Ama in PHALGA, is the incumbency of transferring folklore into readable forms so as to preserve it as well as make it attractive to young readers. Unfortunately, as observed by LABAF (2010), a number of upcoming authors do not have a proper grasp of the African culture hence their reluctance to delve into this area of literature. Apparently, they cannot give what they do not have.

The focus group and the interviewees generally agreed to the fact that government needs to do more in preserving folklore activities. In Rivers State, for instance, legislation should be enacted to protect copyrights on folklore and other cultural innovations and inventions. This, respondents noted, will encourage more persons to delve into material culture (crafts, local designs, boat carving, among others). In this light, the United Nations' Educational, Scientific and Cultural Organization (UNESCO) and the World International Property Organization (WIPO) in 1997 proposed efforts for the 'Intellectual Property Protection of Expressions of Folklore'. As the Executive summary declares, "the 1989 UNESCO Recommendations on the Safeguarding of Traditional Culture and Folklore is generally recognized as the highest profile declaration on the importance of intangible heritage in the world" (UNESCO - WIPO, 1997 cited in Yahaya, 2015). Yahaya noted that the Asia Pacific Centre of Education for International understanding under the Auspices of UNESCO and their project "Telling Tales from Southeast Asian and Korea, have extended itself to inculcate the sharing of cultural traditions and folklore to the Southeast Asian region inclusive of Korea. Yahaya again noted that the project gathers a wide range of folktales from eleven Southeast Asian countries and Korea, in which primary school children can read or watch folktales from their own country or from other partner countries. This, he, maintained "is a noble effort in encouraging the sharing of cultural traditions with a wider community in an effort to not only preserve traditional stories but that the folktales of a given society do not lose their cultural identity" (p.570).

Consequently, the argument remains that frantic efforts must be made to preserve and reawaken the culture of the Amadi-Ama people. This is in view of the fact that "a nation or continent whose cultural values (the basis of its tourist attraction for economic viability) gradually sink into the sand of extinction will soon cease to enjoy universal respect, admiration, uniqueness and identity (http:/ / ijawoodlandpark.com/ the-need-for-reawakening). 


\section{Conclusion and Recommendations}

A number of folkloric activities indeed take place in Amadi-Ama. Top among them are the Iria puberty and marriage ceremonies, wrestling, traditional plays/games, burial rites, chieftaincy installation and many other rites connected with the day- to- day life of the people. Also, in Amadi-Ama, proverbs which are a symbol of communication act as a catalyst of knowledge, ethics and morals which provoke further reflection and call for deeper thinking and wisdom in consideration of issues.

This, it was discovered, poses a threat to identifiable folkloric activities in Amadi-Ama. Although the early Christian Missionaries did a deal of good by checking unwholesome

practices and customs indulged in by people which saw them establish educational institutions and health centres, they also did harm to the people. They forbade singing native songs and dancing native steps; branding indiscriminately all such exercises as heathen instead of purifying them where necessary. Thus, folkloric activities in Amadi-Ama are on the decline, largely because of Westernization and the advent of Christianity which now see these folkloric activities as sinful.

Also, finding shows that custom lore; marriage, chieftaincy installation burial rites, naming among others still exists. This is not this case with material culture (Canoe carving, net weaving, masquerade carving, artifacts among others) which is on the decline. Yet it was revealed that there is the dearth of documented folklore that could have helped convey ancient thoughts to younger generations of Amadi-Ama.

Folklore and proverbs have continued to energize society towards undertaking ventures that can bring about change. It reveals that proverbs and folklore occupy a very central position in creative arts, oration and moral teachings.

Finally, to promote cultural awakening in Amadi-Ama in PHALGA, findings have shown that there is need to introduce folklore and proverbs in the homes. Schools are equally expected to introduce the teaching of folklore, especially those that can inculcate moral virtues in children and youths. The government is expected to come up with legislation that will protect copyright of intellectual properties on culture and folklore.

African societies are fast losing their essence and identity due to self-denial. Unfortunately, many now wallow in false identity and derail from the path of honour and dignity because it has become difficult to first trace from where they are coming and much more difficult knowing their destination. This is because the African culture and tradition which are a reflection of our uniqueness and identity are on the brink of extinction.

Over the years, folktales, proverbs and cultural activities have been our compass, projecting us into the future and at the same time impressing on our sub-consciousness the glory of the then days. While we might be quick to blame the failing culture of the African society on Western invasion through civilization and Christianity, the effect of this has been more devastating on Africans because we had first resigned ourselves to a second-class status, and as such, opening ourselves to be used and abused. From the outset, we felt inferior. We had first concluded that ours was a culture that thrived in retrogression and indolence. This is where we lost it. Because no society can extricate itself from its culture and tradition, there is the urgent need to return to the path of originality. Therefore, folklore, folktales, proverbs and their likes are the vehicles we need to return to our true being and the core essence of our existence as a people. It is only when this is done that we can successfully attain heights as a distinct people; as Africans and indeed as people from Amadi-Ama.

From the findings and conclusion, the following recommendations are here proffered:

- That in line with the suggestions of the FGD participants, there is an urgent need to design a road map for the cultural reawakening of the Amadi-Ama people. More important in this regard is the need to introduce folklore in homes by parents. Beyond engaging children in folkloric activities is the need for parents to explain to them the import and implication of these activities for their well-being.

- Priority should be given to the teaching of folklore in schools, especially those that could inculcate moral virtues in children and youths.

- It is equally important that this folklore be converted into readable forms in books and on the Internet, so as to not only preserve it but for it to also attract younger readers.

- But then, governments can come up with incentives to attract authors who may be willing to delve into African literature. This is to mitigate the rising dearth of African literature in the literary circle.

- Key stakeholders in Amadi-Ama can from time to time organize seminars on folkloric activities and native proverbs to reawaken the cultural consciousness of youths of the community.

\section{References}

i. Adesoji, O. (2005). Globalization and its implication on African culture and development: Challenges for education. International Journal of African \& African- American Studies, 4(2), 9-21.

ii. Babara, K. \& Walker, W.S. (1961) Nigerian folktales. New Jersey: Rutgers University, New Brunswick.

iii. Hamer, L. (1999). A folkloristic approach to understanding teachers as storytellers. Qualitative Studies in Education, 12 (4), 363- 380

iv. Hufford, M. (1991). American folklife: A commonwealth of cultures. Washington: American Folklife Centre, Library of Congress.

v. Kanagy, C. L. \& Kraybill, D.B. (1999). The riddles of human society. USA: SAGE Publications Inc.

vi. Klein, B. (2001) Folklore. International Encyclopedia of the Social and Behavioral Sciences. 8, 5711-5715.

vii. NBF (2010). LABAF 2010: Of vanishing folklore in Nigerian interactive. Retrieved Jan. 16, 2016 from www.nigerianbestforum.com.

viii. Nwanne, B.U (2006). Speech, proverb and folklore aesthetics in traditional African communication system. Journal of Media and Aesthetics (1) 2, pp.11-25. 
ix. Opuogulaya, E.D.W. (1975). The cultural heritage of Wakirike: The Okrika people. Port Harcourt: Rivers State Council for Arts and Culture.

x. Patton, M. Q. (2014). Qualitative research \& evaluation methods: Integrative theory and practice. New York: SAGE Publications.

xi. Penjore, D. (2005). Folktales and education: Role of Bhutanese folktales in value transmission. Centre for Bhutan Studies, $47-73$.

xii. Sims, M. C. \& Stephens, M. (2005). Living folklore: An introduction to the study of people and their traditions. Logan: Utah State University Press

xiii. Sutherland, E.T. (1976). The playwright's opportunity in drama for our children. Paper presented at the Seminar on Writing and Production for Children, April 5 - 10, 1976.

xiv. Udoakah, N. (1998). Development communication. Ibadan: Stirling-Horden Publishers (Nig) Ltd.

xv. Warta, K. (2012). Developing students' moral value through folklore in multilingual setting: A case study in the development of morality. Delhi Business Review.13 (1).

xvi. Yahaya, W. A. W. (2015). Transcending the folktale: From storytelling to Estories. Paper presented at International Conference on Education, Social Sciences and Humanities, 569 - 572. 